\title{
Cryptodrassus bungaricus and Leptodrassex memorialis from Crimea (Aranei: Gnaphosidae)
}

\author{
Cryptodrassus bungaricus и Leptodrassex memorialis из Крыма \\ (Aranei: Gnaphosidae)
}

\author{
Mykola M. Kovblyuk, Anton A. Nadolny \\ Н.М. Ковблюк, А.А. Надольный
}

Zoology Department, National Taurida V.I. Vernadsky University, Yaltinskaya Street 4, Simferopol 95007 Ukraine. E-mail: kovblyuk@mail.ru

Кафедра зоологии Таврического национального университета им. В.И. Вернадского, ул. Ялтинская 4, Симферополь 95007 Украина.

KEY WORDS: spiders, Cryptodrassus hungaricus, Leptodrassex memorialis, new combination, new record, redescription, phenology, Crimea.

КЛЮЧЕВЫЕ СЛОВА: пауки, Cryptodrassus hungaricus, Leptodrassex memorialis, новая комбинация, новая находка, переописание, фенология, Крым.

ABSTRACT. Two species, Cryptodrassus hungaricus (Balogh, 1935) and Leptodrassex memorialis (Spassky, 1940) comb.n. ex Leptodrassus, are recorded from Crimea. C. hungaricus is a species new to Crimea and Ukraine. Diagnostic drawings, distribution and phenology are provided for these species.

РЕЗЮМЕ. Два вида, Cryptodrassus hungaricus (Balogh, 1935) и Leptodrassex memorialis (Spassky, 1940) comb.n. ex Leptodrassus, обнаружены в Крыму. C. hungaricus впервые отмечен для Украины. Приведены диагностические рисунки, данные о распространении и фенологии этих видов.

\section{Introduction}

This paper continues our studies of Crimean gnaphosid spiders. So far 65 gnaphosid species belonging to 18 genera have been reported from the Peninsula [Kovblyuk, 2004, 2006; Kovblyuk \& Tuneva, 2009; Kovblyuk et al., 2009]. More species were found during the study of the Karadag Nature Reserve. The goal of this paper is the redescription of two little-known gnaphosid species with extremely small body size and pale coloration.

\section{Material and Methods}

Specimens for this study were recently collected in Crimea. All specimens are deposited in the collection of Zoology Department, V.I. Vernadsky Taurida National University, Simferopol, Ukraine, M.M. Kovblyuk (TNU).

The following abbreviations are used in the text: a — apical; d - dorsal; pl — prolateral; $\mathrm{rl}$ - retrolateral; v - ventral. Terms and abbreviations for genital descriptions used in the text and for illustrations: $A p$ anterior pocket of epigyne; Ats - apical tegular sclerite ( = functional conductor); $C o-$ copulatory opening; $E$ - embolus; $F d$ - fertilization duct; $G$ - spermathecal gland; $M A$ - median apophysis; $R$ - spermatheca (receptaculum); RTA — retrolateral tibial apophysis; To - tegular outgrowth.

Coloration was described from specimens preserved in $75 \%$ ethanol with added glycerin ( $9: 1$ by volume). Legs and palpal segments were measured after separation from the cephalothorax. All measurements are in $\mathrm{mm}$. All scale bars are equal to $0.1 \mathrm{~mm}$.

\section{Cryptodrassus Miller, 1943}

Type species: C. pulchellus Miller, 1943 (from Moravia, Czech Republic) [Miller, 1943], is considered as a junior synonym of Zelotes hungaricus Balogh, 1935 (from Hungary) [Weiss et al., 1998].

Cryptodrassus contains only two species: C. hungaricus (Balogh, 1935) recorded from South and East Europe and C. creticus Chatzaki, 2002, recorded from Crete and Turkey [Platnick, 2010]. Some undescribed species were reported from Kenya [Ovtsharenko et al., 1994] and Spain [Murphy, 2007]. Cryptodrassus is closely related to Synaphosus Platnick \& Shadab, 1980. The genus Synaphosus is distributed from France south to Kenya, and east to Kazakhstan and Pakistan, with one species occurring in USA and Mexico. Cryptodrassus can be distinguished by the following combination of characters: little body size and pale coloration, posterior median eyes larger than the other eyes (Figs. 1, 7), male abdomen with a dorsal scutum, and with peculiar constructions of male bulbus and female epigyne (Figs 4-6, 8-11) [Murphy, 2007: 65]. 


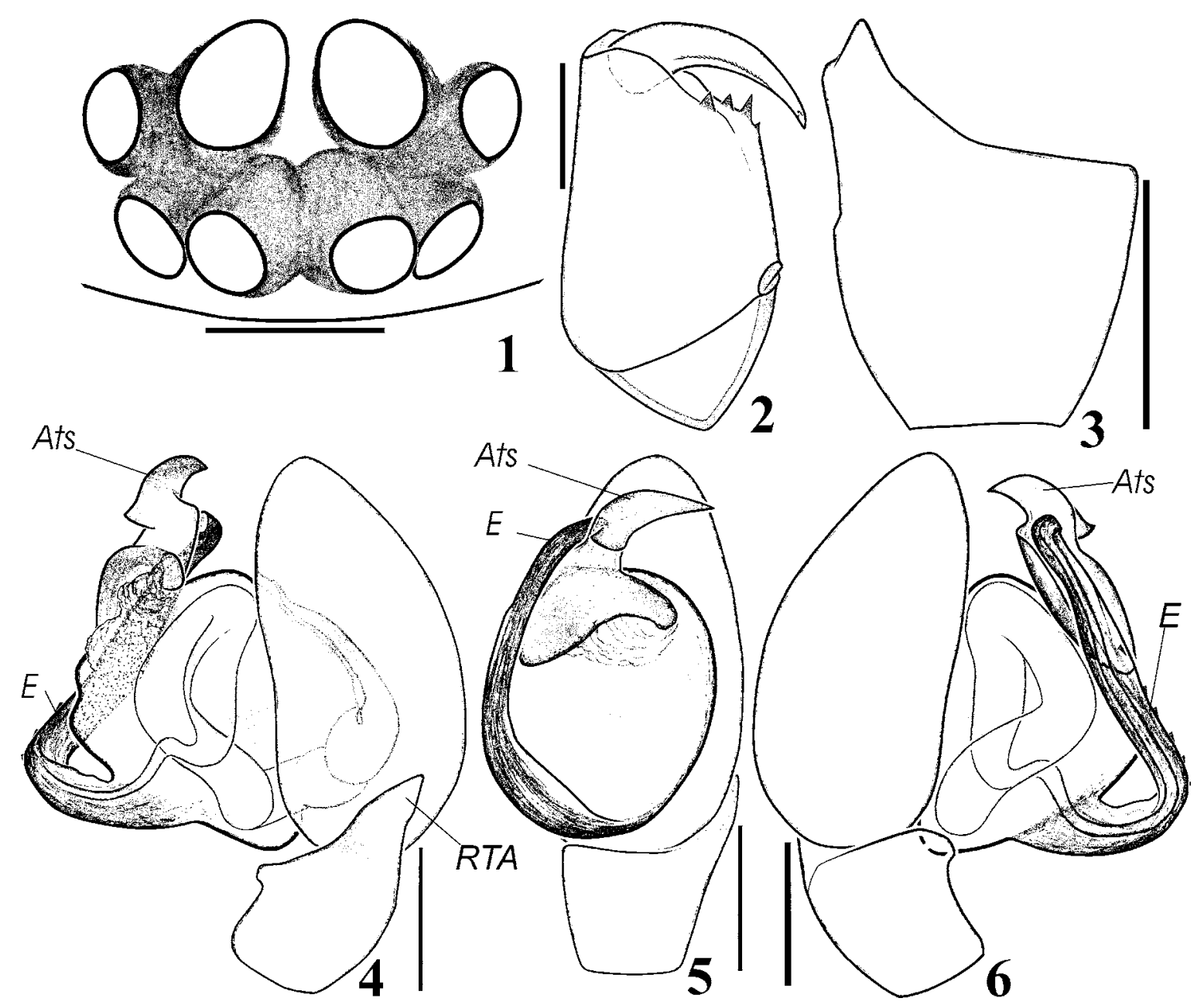

Figs 1-6. Male of Cryptodrassus hungaricus: 1 - eyes, frontal view; 2 - chelicerae, posterior view; 3 - palpal tibia, dorsal view; 4 - palp, retrolateral view; 5 - palp, ventral view; 6 - palp, prolateral view.

Рис. 1-6. Самец Cryptodrassus hungaricus: 1 - глаза, спереди; 2 - хелицера, сзади; 3 - голень пальпы, дорсально; 4 пальпа, ретролатерально; 5 - пальпа, вентрально; 6 - пальпа, пролатерально.

Cryptodrassus hungaricus (Balogh, 1935) Figs 1-19.

C. pulchellus Miller, 1943: 2-6, tab. I, f. 2-6 ()). C. pulchellus: Miller, 1947: 55-57, tab. II, f. 4a-c (9)

C. pulchellus: Miller, 1971: 81, pl. VI, f. 13-14 (O').

C. pulchellus: Ovtsharenko et al., 1994: 3, f. 7-11 ( (

C. h.: Weiss et al., 1998: 57-58, f. 1-4 (O'ㅇ)

C. h.: Ledoux \& Rollard, 2004: 16, f. 1A-F (O'o).

C. h.: Trotta, 2005: 60, 164-165, f. 270-273 (०'0).

C. h.: Murphy, 2007: 65-66, f. 528-529 (O'P).

For a complete list of references see Platnick [2010].

MATERIAL. UKRAINE, CRIMEA. Feodosiya Distr.: $20^{7} 0^{7}$, 6 우우 (TNU-2595/21), Karadag Nature Reserve, Lobovoy Mt. Range, 28.05.2008, A.A. Nadolny.

DIAGNOSIS. C. hungaricus differs from the other species of the genus, $C$. creticus, by the shape of RTA and presence of peculiar denticles on the embolus (lacking in C. creticus, but present in some Synaphosus species [Ovtsharenko et al., 1994; Murphy, 2007: 536]), shape of epigyne [Murphy, 2007: 537], by larger posterior median eyes both in males and females (in $C$. creticus posterior median eyes not larger than the other eyes — see Murphy [2007: 539]), one retromarginal tooth on each chelicera (2 retromarginal teeth in $C$. creticus - see Murphy, 2007: 538).

C. hungaricus is distinguished from all the other gnaphosid species in the Crimean fauna by having the smallest body size and an extremely light pale coloration.

DESCRIPTION. Measurements $\left(\sigma^{\pi} /+\right)$ : total length 2.0 / 2.4; carapace 0.8 / 0.9 long, 0.6 / 0.6 wide. Length of leg segments (male / female) see in Table 1.

Length of male palp segments: femur 0.3, patella 0.1 , tibia 0.1 , cymbium 0.3 . Length of female palp segments: femur 0.2 , patella 0.1 , tibia 0.1 , tarsus 0.1 .

Male leg spination. Femur: I - d 1-1; II - d 1-1; III - d 1-1, pl 1, rl 1; IV - d 1-1, rl 1. Tibia: I - v 22-2a; II - v 1-1-2a; III - d 1, pl 1-1, rl 2-1, v 1-2-2a; IV - pl 1-2, rl 2-2, v 2-2-2a. Metatarsus: I - v 2-2; II — v 2-2; III - pl 1-2, rl 2-2, v 2-1a; IV - pl 2-2, rl 2$2, \mathrm{v} 1-1$. 

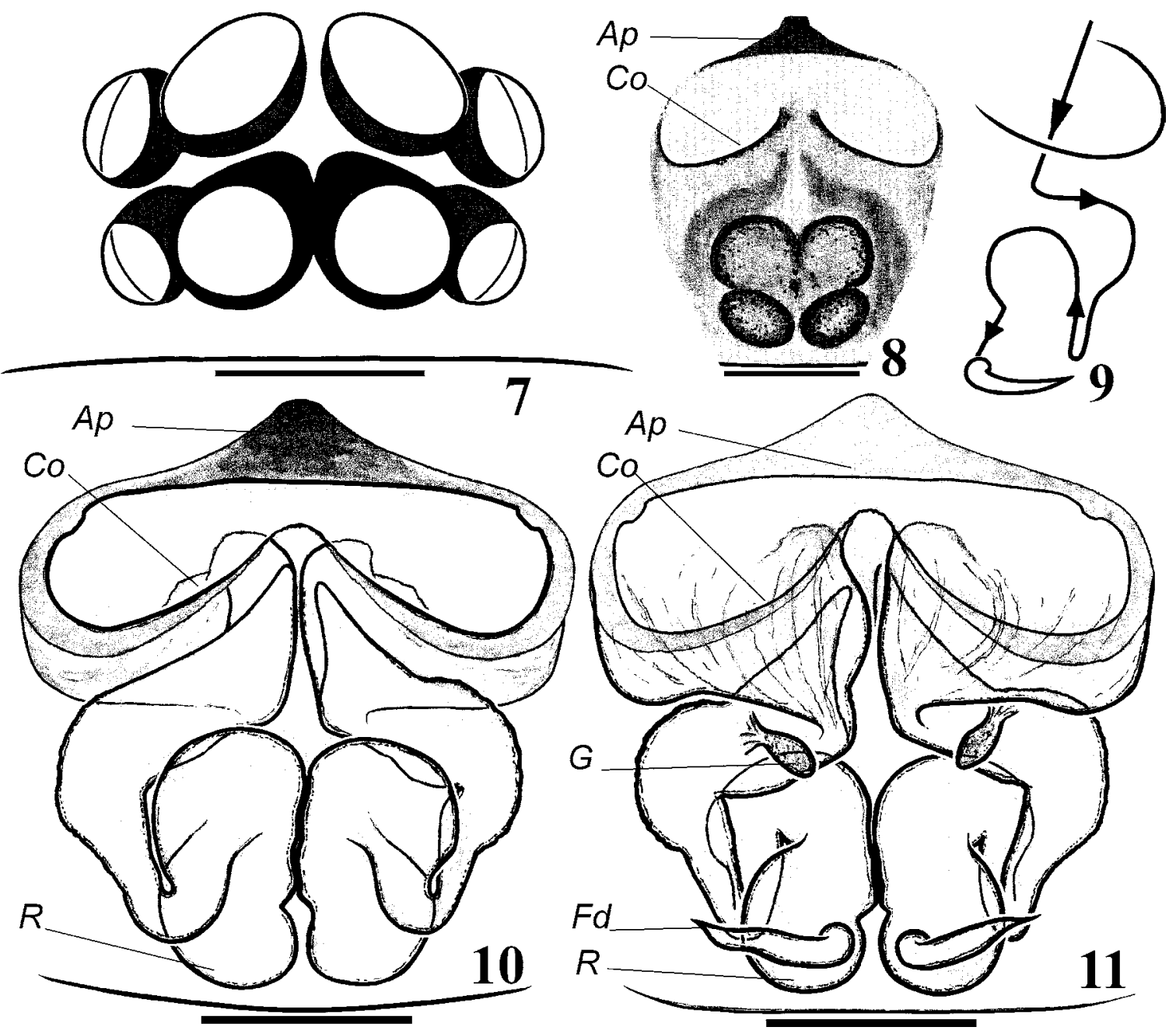

Figs 7-11. Female of Cryptodrassus hungaricus: 7 - eyes, frontal view; 8 - epigyne, ventral view; 9 - schematic course of spermathecae duct trajectory; 10 - epigyne, ventral view (after maceration); 11 - epigyne, dorsal view (after maceration).

Рис. 7-11. Самка Cryptodrassus hungaricus: 7 - глаза, спереди; 8 - эпигина, вентрально; 9 - схема траектории каналов сперматеки; 10 - эпигина, вентрально (после мацерации); 11 - эпигина, дорсально (после мацерации).

Table 1. Length of leg segments (male / female).

Таблица 1. Длина члеников ног (самец / самка).

\begin{tabular}{|l|c|c|c|c|c|c|}
\hline \multicolumn{1}{|c|}{ Leg } & Femur & Patella & Tibia & Metatarsus & Tarsus & Total length \\
\hline I & $0.5 / 0.5$ & $0.3 / 0.3$ & $0.4 / 0.4$ & $0.3 / 0.3$ & $0.3 / 0.2$ & $1.8 / 1.7$ \\
\hline II & $0.4 / 0.4$ & $0.3 / 0.3$ & $0.3 / 0.3$ & $0.3 / 0.3$ & $0.2 / 0.2$ & $1.5 / 1.5$ \\
\hline III & $0.4 / 0.4$ & $0.2 / 0.2$ & $0.2 / 0.2$ & $0.3 / 0.3$ & $0.2 / 0.2$ & $1.3 / 1.3$ \\
\hline IV & $0.5 / 0.5$ & $0.4 / 0.3$ & $0.4 / 0.4$ & $0.5 / 0.4$ & $0.3 / 0.3$ & $2.1 / 1.9$ \\
\hline
\end{tabular}

Female leg spination. Femur: $\mathrm{I}-\mathrm{d} 1-1 ; \mathrm{II}-\mathrm{d} 1-1$; III - d 1-1; IV - d 1-1, rl 1. Tibia: III - pl 1-1, rl 1, v 2-2a; IV - pl 1-1, rl 2-2, v 2-2a. Metatarsus: I - v 2-2; II - v 2-2; III - pl 2-2, rl 1-2, v 2-1; IV - pl 2-2, rl 1-2-2, v 2-1.

Chelicerae with three promarginal teeth and one retromarginal tooth in males and females.

Carapace, sternum, legs and palps, chelicerae and abdomen are a unicolourous pale grey, without pattern. General appearance: male - Figs 12-13; female Figs 14-15.
Male palp: Figs 3-6, 17; epigyne: Figs 8-11, 18-19. RTA short and wide. Base of embolus is located at the base of bulbus. Embolus is wide and has peculiar denticles. Epigyne with wide fovea and with wide copulatory openings in fovea. Spermathecal glands are small.

VARIATION. Male total length $(n=2)$ various from 1.8 to 2.0 ; however, carapace length and width were equal in the examined specimens $(0.8$ and 0.6 respectively). Female total length $(n=5)$ various from 2.0 to 2.6; female carapace length - from 0.8 to 1.0 ; width - from 0.6 to 0.7 . 


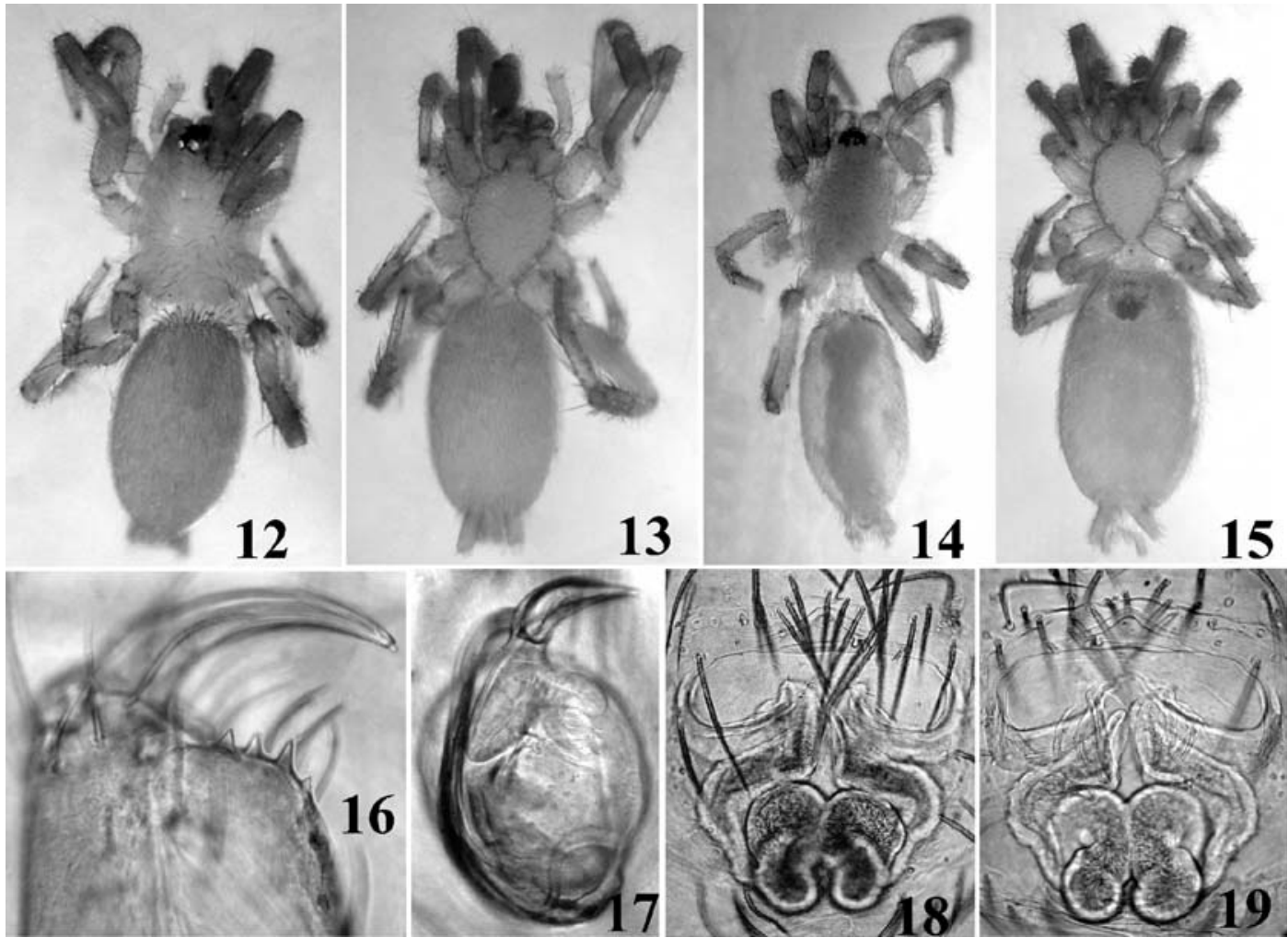

Figs 12-19. Cryptodrassus hungaricus: 12 - male general appearance, dorsal view; 13 - male general appearance, ventral view; 14 - female general appearance, dorsal view; 15 - female general appearance, ventral view; 16 - male chelicerae, posterior view; 17 bulbus, ventral view; 18 - epigyne, ventral view; 19 - epigyne, dorsal view.

Рис. 12-19. Cryptodrassus hungaricus: 12 - габитус самца, дорсально; 13 - габитус самца, вентрально; 14 - габитус самки, дорсально; 15 - габитус самки, вентрально; 16 - хелицера самца, сзади; 17 - бульбус, вентрально; 18 - эпигина, вентрально; 19 - эпигина, дорсально.

TYPE LOCALITY. Hungary, near Budapest [Weiss et al., 1998].

DISTRIBUTION. France, Italy, Hungary, Czech Republic, Slovakia, Romania, Rostov Area of Russia [Weiss et al., 1998; Nentwig et al., 2003; Ledoux \& Rollard, 2004; Trotta, 2005; Ponomarev \& Tsvetkov, 2006; Murphy, 2007], Ukraine (Crimea) — new record.

NOTE. Some authors mentioned that this species is extremely rare in collections [Ponomarev \& Tsvetkov, 2006; Murphy, 2007].

HABITATS. Very dry sub-mediterranean steppe on south slope.

PHENOLOGY: $O^{7}+-\mathrm{V}$.

Leptodrassex Murphy, 2007

Type species: Leptodrassus simoni Dalmas, 1919.

Leptodrassex contains only three described species: type species L. simoni (Dalmas, 1919) from Portugal, Spain, France and Lebanon; L. hylaestomachi (Berland, 1934) from Canary Islands and L. algericus (Dalmas, 1919) from Algeria [Platnick, 2010]. Two undescribed species were reported from Kenya [Murphy, 2007: X]. Probably some of 11 the described Mediterranean species from the genus Leptodrassus Simon, 1878, should be transferred to Leptodrassex [Murphy, 2007: X, 61; Platnick, 2010].
According to Murphy [2007], Leptodrassex can be distinguished by combination of characters: small size; pale coloration; 2-3 small teeth on cheliceral retromargin and 2-4 on the promargin; males without the dorsal scutum; anterior median eyes are remarkably larger than the others.

The genus Leptodrassex is related to the genus Leptodrassus, with the main differences as given in the Table 2 [after: Murphy, 2007: 504-505, 512, 518519; Levy, 2009: 7-8, f. 8-10, 12, 15].

Taking into account that Leptodrassus memorialis Spassky, 1940, is similar in above-mentioned characteristics to the type species of the genus Leptodrassex, and is not similar to the type species of the genus Leptodrassus, we established new combination: Leptodrassex memorialis (Spassky, 1940) comb.n. ex Leptodrassus. The genus Leptodrassex is distributed from Canary Islands and Portugal east to Mongolia and south to Kenya.

Leptodrassex memorialis (Spassky, 1940), comb.n. Figs 20-39.

Leptodrassus m. Spassky, 1940: 355-357, t. 7, f. 2-5 (О7o). Leptodrassus nemoralis: Eskov \& Marusik, 1995: 77, f. 45-47 $\left(\sigma^{\top}+\right)$.

Leptodrassus m.: Tuneva \& Esyunin, 2002: 218-219, f. 7-10 $\left(\sigma^{7}+\right)$. 

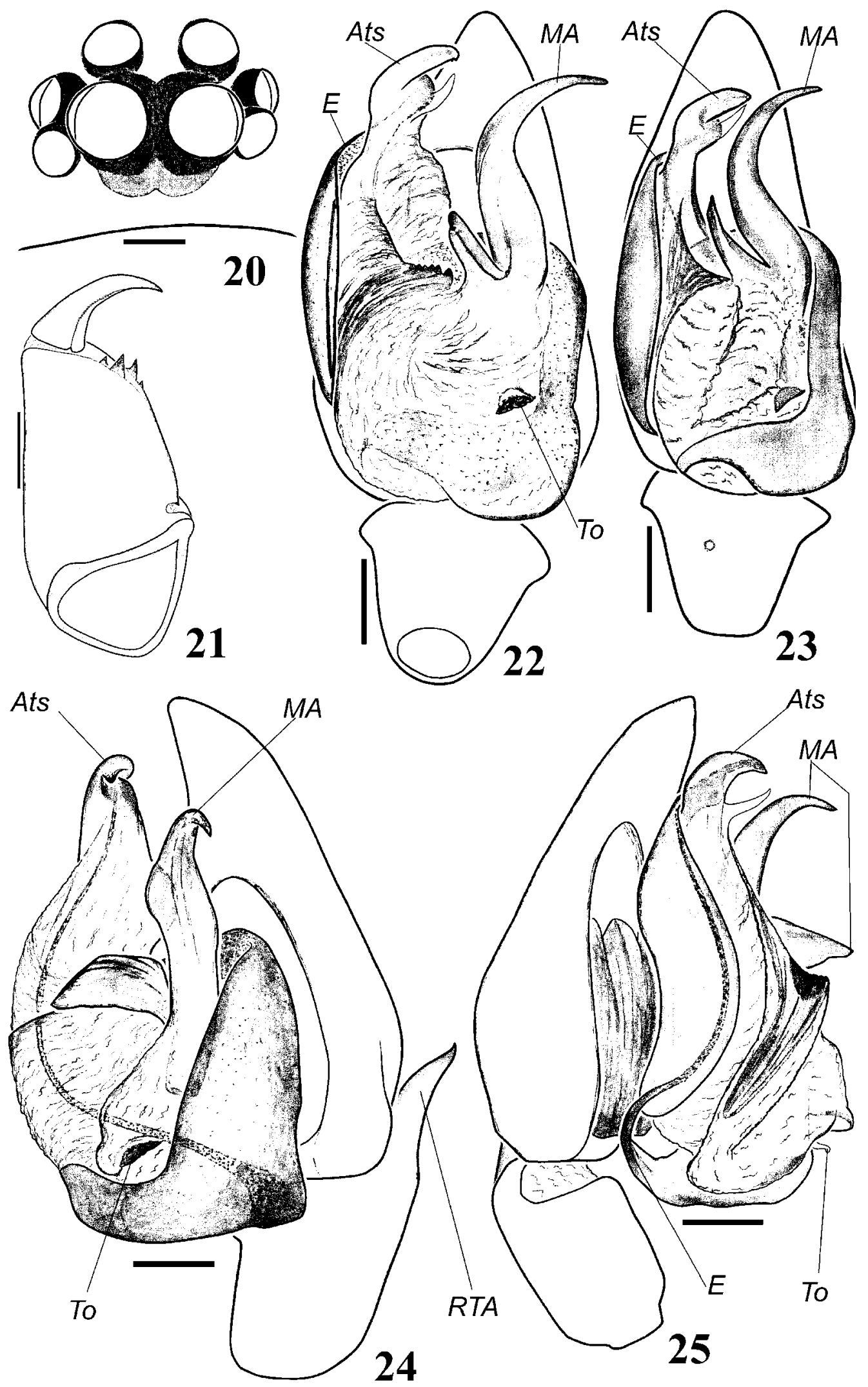

Figs 20-25. Male of Leptodrassex memorialis: 20 - eyes, frontal view; 21 - chelicerae, posterior view; 22 - palp, ventral view (after maceration); 23 - palp, ventral view (without maceration); 24 - palp, ventro-retrolateral view; 25 - palp, prolateral view.

Рис. 20-25. Самец Leptodrassex memorialis: 20 - глаза, спереди; 21 - хелицера, сзади; 22 - пальпа, вентрально (после мацерации); 23 - пальпа, вентрально (без мацерации); 24 - пальпа, вентро-ретролатерально; 25 - пальпа, пролатерально. 


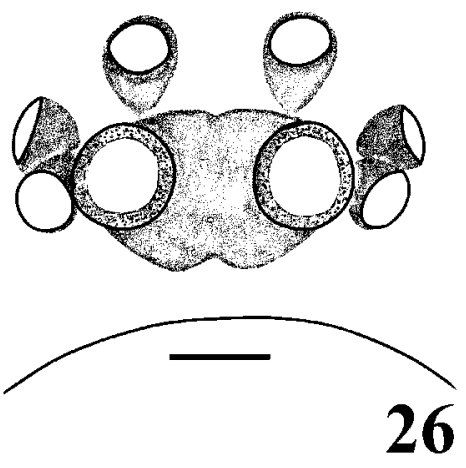


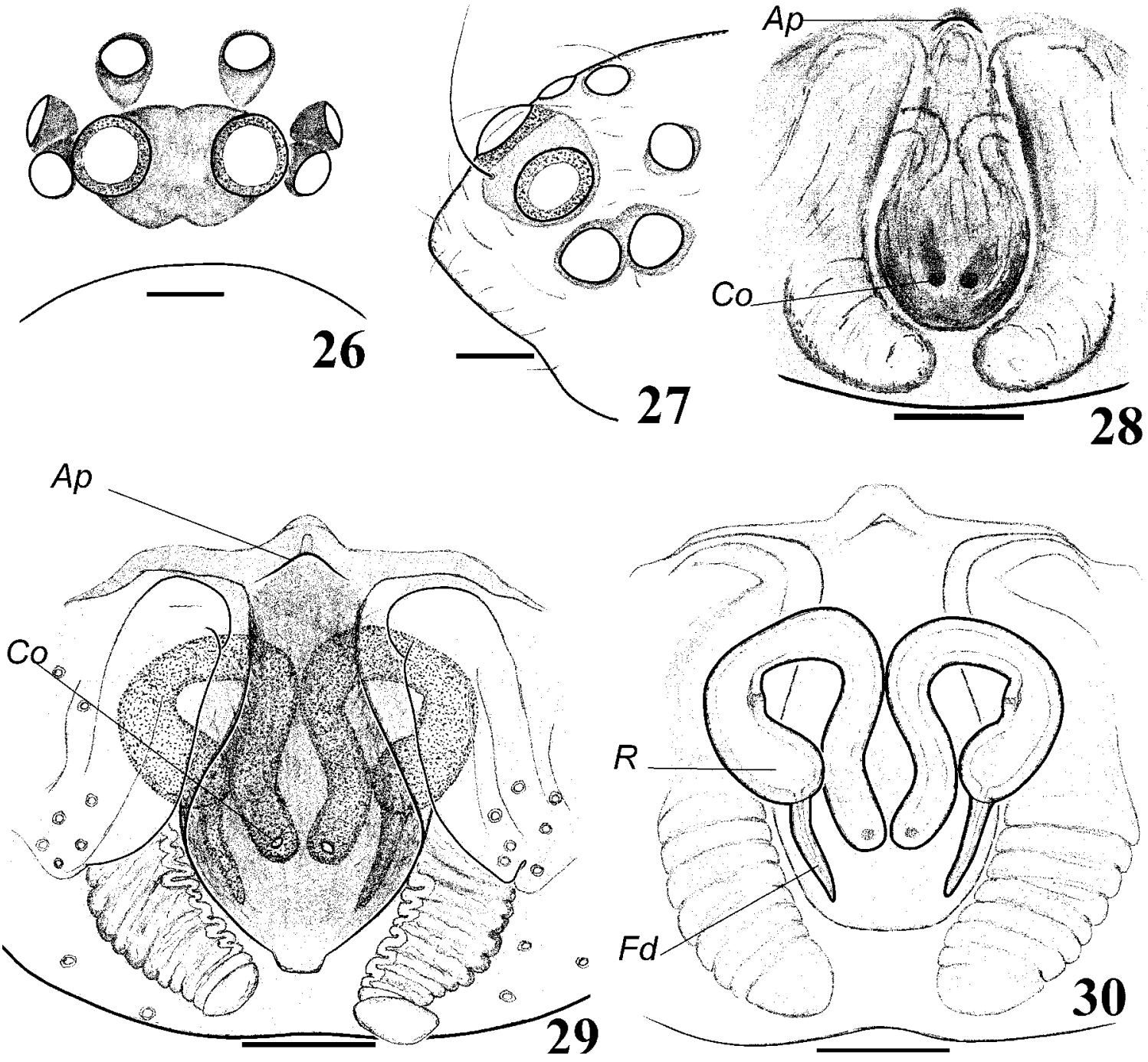

Figs 26-30. Female of Leptodrassex memorialis: 26 - eyes, frontal view; 27 - eyes, lateral view; 28 - epigyne, ventral view; 29 epigyne, ventral view (after maceration); 30 - epigyne, dorsal view (after maceration).

Рис. 26-30. Самка Leptodrassex memorialis: 26 — глаза, спереди; 27 — глаза, сбоку; 28 - эпигина, вентрально; 29 — эпигина, вентрально (после мацерации); 30 - эпигина, дорсально (после мацерации).

Table 2. Differences between Leptodrassex and Leptodrassus.

Таблица 2. Различия родов Leptodrassex и Leptodrassus.

\begin{tabular}{|l|c|c|}
\hline & Leptodrassex & Leptodrassus \\
\hline Type species & L. simoni (Dalmas, 1919) & L. femineus (Simon, 1873) \\
\hline $\begin{array}{l}\text { Teeth on the cheliceral } \\
\text { retromargin }\end{array}$ & 2-3, small and conical (Figs 21,35) & absent \\
\hline Tegular outgrow & present (Figs 22-25) & $\begin{array}{c}\text { absent or small } \\
\text { (Figs 28-30,38-39) }\end{array}$ \\
\hline $\begin{array}{l}\text { Scape of epigyne } \\
\text { present; large, covers part of epigynal plate, is } \\
\text { dark and very visible }\end{array}$ \\
\hline
\end{tabular}

RECORDS FROM CRIMEA: Kovblyuk, 2004, 2006; Kovblyuk et al., 2008 - all as Leptodrassus.

MATERIAL. UKRAINE, CRIMEA. Sevastopol Distr.: 1 ㅇ (TNU), right side of Chornaya Riv. canyon, Juniperus excelsa, 23.05.2000, M.M. Kovblyuk; $1 \sigma^{\top}$ (TNU-1973/9), right side of canyon of Uzundzha Riv. near Uzundzha Vil. (= Kolkhoznoe), 6.06.2005, O.V. Kukushkin; Feodosiya Distr.: 1 O (TNU-1766/5), Karadagh Nature Reserve, Beregovoy Mt. Range, Juniperus excel- sa, 28.05.2003, M.M. Kovblyuk; 1 ㅇ (TNU-2041/6), same place, Khoba-Tepe Mt. Range, 19.06.2004, O.V. Kukushkin; 2 우 (TNU1975/4), same place, Kara-Arach Mt. Range, 1.06.2005, O.V. Kukushkin; $2 \sigma^{7} \sigma^{\top}, 1$ (TNU-2594/4), same place, Magnytny Mt. Range, Stipa steppe, 27.05.2008, A.A. Nadolny; 1 (TNU2595/19), same place, Lobovoy Mt. Range, 28.05.2008, A.A. Nadolny; $1 \sigma^{7}$ (TNU-2596/7), same place, Khoba-Tepe Mt. Range, 30.05.2008, A.A. Nadolny; 1 o (TNU-2597/5), same place, 

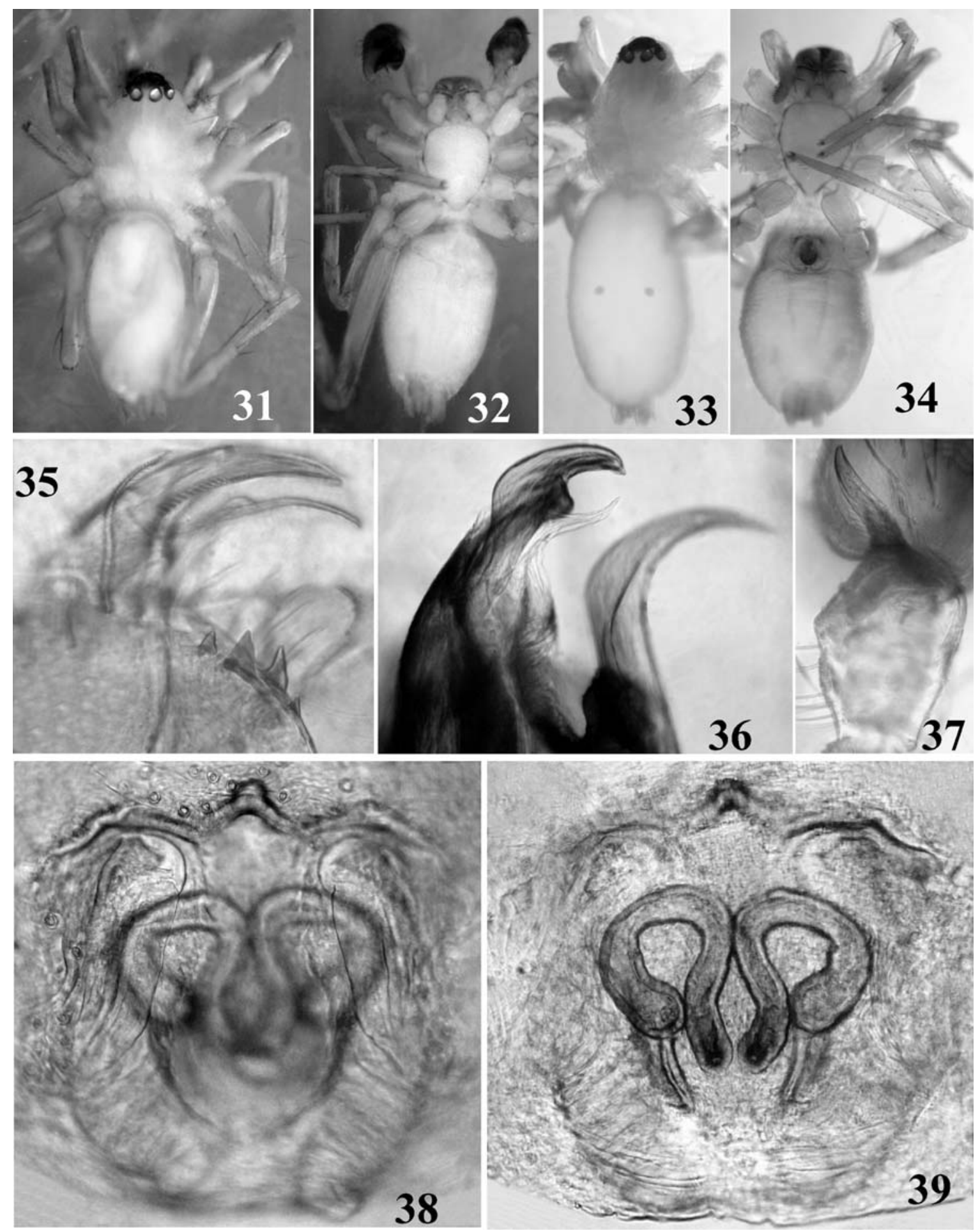

Figs 31-39. Leptodrassex memorialis: 31 - male general appearance, dorsal view; 32 - male general appearance, ventral view; 33 - female general appearance, dorsal view; 34 - female general appearance, ventral view; 35 - male chelicerae, posterior view; 36 male apical part of bulbus, prolateral view; 37 - male palpal tibia, retrolateral view; 38 - epigyne, ventral view; 39 - epigyne, dorsal view.

Рис. 31-39. Leptodrassex memorialis: 31 - габитус самца, дорсально; 32 - габитус самца, вентрально; 33 - габитус самки, дорсально; 34 - габитус самки, вентрально; 35 - хелицера самца, сзади; 36 - апикальная часть бульбуса, пролатерально; 37 голень пальпы самца, ретролатерально; 38 - эпигина, вентрально; 39 - эпигина, дорсально. 
Table 3. Length of leg segments (male / female)

Таблица 3. Длина члеников ног (самец / самка)

\begin{tabular}{|l|c|c|c|c|c|c|}
\hline Leg & Femur & Patella & Tibia & Metatarsus & Tarsus & Total length \\
\hline I & $1.1 / 0.8$ & $0.4 / 0.4$ & $0.9 / 0.6$ & $0.8 / 0.5$ & $0.6 / 0.4$ & $3.8 / 2.7$ \\
\hline II & $1.0 / 0.7$ & $0.4 / 0.4$ & $0.9 / 0.6$ & $0.7 / 0.5$ & $0.5 / 0.4$ & $3.5 / 2.6$ \\
\hline III & $0.8 / 0.6$ & $0.4 / 0.5$ & $0.7 / 0.5$ & $0.5 / 0.4$ & $0.4 / 0.3$ & $2.8 / 2.3$ \\
\hline IV & $1.3 / 1.0$ & $0.5 / 0.5$ & $1.0 / 0.8$ & $1.1 / 0.9$ & $0.4 / 0.3$ & $4.3 / 3.5$ \\
\hline
\end{tabular}

Kara-Agach Mt. Range, Juniperus excelsa, 30.05.2008, A.A. Nadolny.

DIAGNOSIS. Leptodrassex memorialis differs from other congeners (L. algericus, L. hylaestomachi and $L$. simoni) by the shape of the RTA, bulbus and epigyne. In addition, it differs by 2 promarginal teeth on male chelicerae: the distal tooth is large and the proximal tooth is small (Fig. 21). L. algericus and L. simoni have 3 promarginal teeth, L. hylaestomachi has 2 teeth of equal size [Murphy, 2007: 506].

DESCRIPTION. Measurements $\left(\sigma^{7} /+\right)$ : total length 2.5 / 3.5; carapace $1.1 / 1.2$ length, 0.9 / 0.9 width. Length of leg segments (male / female) see in Table 3.

Length of male palp segments: femur 0.4 , patella 0.2 , tibia 0.2 , cymbium 0.5 . Length of female palp segments: femur 0.4 , patella 0.2 , tibia 0.2 , tarsus 0.3 .

Male leg spination. Femur: I - d 1, pl 1; II - d 1, pl 1; III - d 1-1, pl 1, rl 1; IV — d 1-1, pl 1, rl 1. Tibia: I — v 2; II — v 1; III - pl 1-1, rl 1-1, v 2; IV - pl 11, rl 1-1, v 1-1-2a. Metatarsus: I — v 2; II — v 2; III pl 1-1, rl 1, v 2-3; IV — pl 2-2, rl 1-2, v 2-2.

Female leg spination. Femur: I - d 1, pl 1; II - d 1; III - d 1-1, pl 1, rl 1; IV - d 1-1, pl 1, rl 1. Tibia: I — v 2-2; II - v 1-2; III — pl 1-1, rl 1-1, v 2; IV - pl 1-1, rl 1-1, v 1-1. Metatarsus: I - v 2; II - v 2; III pl 1-1, rl 1, v 2-3; IV - pl 2-2, rl 1-2, v 1-1-2.

Chelicerae have 2 promarginal and 2 retromarginal teeth in males and females (Fig. 21, 35).

Carapace, sternum, chelicerae, legs and palps, abdomen are unicolourous pale yellowish, without pattern, except the bulbus of male palp, which is dark brown. Only 2 (one pair) of apodemes are present on abdomen (Fig. 33). General appearance: male — Fig. 31-32; female - Fig. 33-34.

Male palp: Figs 22-25, 36-37. Palp is relatively large. RTA of male palp long, thin and slightly Scurved. Tegulum with tegular outgrow is located at the base of median apophysis. Median apophysis is large and bifurcated. Apical tegular sclerite (probably functional conductor) has two laminae et the tip.

Epigyne: Figs 28-30, 34, 38-39. Epigyne with well developed fovea and one anterior pocket. In the fovea, two distinct small copulatory openings are distinctly visible. Scape of epigyne is absent. Shape of spermathecal ducts is species-specific.

VARIATION. Male total length $(\mathrm{n}=2)$ various from 2.4 to 2.5 ; male carapace $(\mathrm{n}=8)$ length — from 1.0 to 1.2 ; width - from 0.8 to 0.9 . Female total length $(\mathrm{n}=3)$ variouss from 2.7 to 3.5 ; female carapace $(\mathrm{n}=$ 6) length — from 1.1 to 1.2 ; width — from 0.6 to 0.9 .
TYPE LOCALITY. Kharkiv Area of Ukraine and Rostov Area of Russia - after the syntypes labels data (lectotype is not designated yet) [Spassky, 1940].

DISTRIBUTION. Ukraine (Kharkiv and Donetsk areas; Crimea), Russia (Rostov, Samara and Orenburg areas; Kalmykia), Kazakhstan (Saur Mt. Range), Mongolia [Spassky, 1940; Eskov \& Marusik, 1995; Prokopenko, 2002; Tuneva \& Esyunin, 2002; Marusik \& Logunov, 2006].

HABITATS. Steppes and sparse Juniperus excelsa forests.

$$
\text { PHENOLOGY: } 0^{7}+\text { - V-VI. }
$$

ACKNOWLEDGEMENTS. Authors are sincerely grateful to O.V. Kukushkin (Karadagh Nature Reserve, Crimea) who collected a lot of interesting spiders in Crimea. We thank many friends and colleagues for the references search, especially Yu.M. Marusik (Magadan, Russia) and D.V. Logunov (Manchester, UK). We thank P.E. Gol'din (Simferopol) for improving the English of the earlier draft. Also authors wish to thank Yu.M. Marusik for his valuable comments to the manuscript and V.I. Ovtsharenko (New York, USA) for the review. The English of the final draft was kindly corrected by Robin Leech (Edmonton, Canada).

This work of M.K. was supported in part by the Karadagh Nature Reserve.

\section{References}

Eskov K.Y., Marusik Y.M. 1995. On the spiders from Saur Mt. range, eastern Kazakhstan (Arachnida: Araneae) // Beitrage zur Araneologie. Bd.4 (for 1994). P.55-94.

Kovblyuk N.M. 2004. [Catalogue of the spiders (Arachnida: Aranei) of the Crimea, South Ukraine] // Voprosy razvitiya Kryma. Vyp.15. Problemy inventarizatsii krymskoi bioty. Simferopol: Tavriya-Plus. P.211-262 [in Russian], 321 [English summary].

Kovblyuk M.M. 2006. [Gnaphosid spiders (Arachnida: Aranei) in Crimean fauna]. Abstract of $\mathrm{PhD}$ thesis. Kyiv: Institute of Zoology Ukrainian Acad. of Sci. 20 p. [in Ukrainian with Russian and English summary].

Kovblyuk M.M., Kukushkin O.V., Gnelitsa V.A., Nadolny A.A. 2008. [Brief atlas of spiders (Arachnida, Aranei) of Karadagh Nature Reserve]. Simferopol: N.Orianda. 120 p. [in Russian]

Kovblyuk M.M., Seyyar O., Demir H., Topcu A. 2009. New taxonomic and faunistic data on the gnaphosid spiders of Turkey (Aranei: Gnaphosidae) // Arthropoda Selecta. Vol.18. No.3-4. P.169-187.

Kovblyuk M.M., Tuneva T.K. 2009. Three interesting species of Gnaphosidae from Crimea (Arachnida: Aranei) // Arthropoda Selecta. Vol.17 (for 2008). No.3-4. P.157-164.

Ledoux J.-C., Rollard C. 2004. De araneis Galliae I.1, Cryptodrassus hungaricus (Balogh) // Revue Arachnologique. T.15. Fasc.2. P.16.

Levy G. 2009. New ground-spider genera and species with annexed checklist of the Gnaphosidae (Araneae) of Israel // Zootaxa. No.2066. P.1-49. 
Marusik Yu.M., Logunov D.V. 2006. On the spiders collected in Mongolia by Dr. Z. Kaszab during expeditions in 1966-1968 (Arachnida, Aranei (excluding Lycosidae)) // Arthropoda Selecta. Vol.15. No.1. P.39-57.

Miller F. 1943. Neue Spinnen aus der Serpentinsteppe bei Mohelno in Mahren // Entomologicke Listy (Folia entomologica). T.6 S.11-29.

Miller F. 1947. Pavouci zvirena hadcových stepi u Mohelna // Archiv Svasu na Vyzkum a ochranu prirody i krajiny v zemi Moravskoslezske (Acta publica Societatis pro cognitione et conservatione naturae in Moraviae Silesiaeque finibus). Vol.7. $107 \mathrm{~s}$

Miller F. 1971. Klic zvireny CSSR. Dil.4: Rad Pavouci-Araneida. Praha: Ceskoslovenska Akademie Ved. S.51-306.

Nentwig W., Hanggi A., Kropf C., Blick T. 2003. Spinnen Mitteleuropas / Central European Spiders. An internet identification key. $<$ http://www.araneae.unibe.ch $>$. Version of 8.12.2003.

Ovtsharenko V.I., Levy G., Platnick N.I. 1994. A review of the ground spider genus Synaphosus (Araneae, Gnaphosidae) // American Museum Novitates. No.3095. 27 p.
Platnick N.I. 2010. The World Spider Catalog. Version 11.0. American Museum of Natural History. Online et: <http:// research.amnh.org/entomology/spiders/catalog/incex.html $>$.

Ponomarev A.V., Tsvetkov A.S. 2006. [New and rare spiders of family Gnaphosidae (Aranei) from a southeast of Europe] // Kavkazskiy entomologicheskiy bulleten'. Vol.2. No.1. P.5-13 [in Russian, with English summary].

Prokopenko E.V. 2002. [About spider fauna (Aranei) of southeast of Ukraine] // Izvestiya Khar'kovskogo entomologicheskogo obshchestva. Vol.9. No.1-2. P.185-192 [in Russian].

Spassky S. 1940. Araneae palaearcticae novae. V // Folia zoologica et hydrobiologica. Vol.10. No.2. P.353-364.

Trotta A. 2005. Introduzione ai ragni italiani (Arachnida Araneae) // Memorie della Societa Entomologica Italiana. Vol.83. P.3-178.

Tuneva T.K., Esyunin S.L. 2002. A review of the family Gnaphosidae in the fauna of the Urals (Aranei), 2. New and rare genera // Arthropoda Selecta. Vol.10 (for 2001). No.3. P.217-224.

Weiss I., Szinetar C., Samu F. 1998. Zur Taxonomie von Cryptodrassus hungaricus (Balogh, 1935) (Araneae: Gnaphosidae) // Arachnologische Mitteilungen. H.16. S.56-59. 